\title{
The process of diagnosing an electrostatic precipitator's state during operation in the energy sector
}

\author{
Aleksandra Brzezińska ${ }^{1,{ }^{*}}$, and Bogdan Żółtowski ${ }^{1}$ \\ ${ }^{1}$ University of Science and Technology, Mechanical Engineering Department, \\ Al. Prof. S. Kaliskiego 7, 85-796 Bydgoszcz, Poland
}

\begin{abstract}
The paper proposes procedures for diagnosing the electrostatic precipitator's technical state in terms of its key function as a facility in a complex waste gas dedusting system. The presented state diagnosing procedures concern the assessment, genesis and forecast of the electrostatic precipitator's state during its rational operation.
\end{abstract}

\section{Introduction}

The Polish energy sector started developing rapidly in the 1960 s when forced industrialisation triggered a sudden demand for electricity. When power plants were constructed, no one realised that power units would have to be temporarily shut down for reasons other than emergencies or repairs [1]. To facilitate the process of planning service activities, modernisations and repairs of any failures of the facility, an appropriate methodology for controlling the electrostatic precipitator's operation and diagnosing its individual components' degradation should be applied. The actions taken will make it possible to improve the electrostatic precipitator's operation and will significantly reduce costs of maintaining its operability during the facility's operation [18].

\section{Environmental protection in the energy sector - legislation}

Long-term draft amendments to energy policy were issued by the European Commission as a Green Paper including issues related to a European strategy for sustainable, competitive and secure energy [2]. Directive 2010/75/EU of the European Parliament and of the Council of 24 November 2010 on industrial emissions (replacing Directive 96/61/EC (IPPC) and a BAT reference document) brought about key transformations in Polish law, more specifically environmental protection regulations [3]. The most important amendments relate to making regulations on emission standards for industrial lobbies more restrictive. In particular, the IED Directive provides for reducing sulphur dioxide, nitrogen oxides and dust generated by combustion plants. The Polish energy sector is also subject to two Regulations of the Minister of the Environment providing for intensifying proecological activities:

- Regulation of the Minister of the Environment of 30 October 2014 on the requirements for the measurement of emissions and the measurement of the amount of water taken [4].

- Regulation of the Minister of the Environment of 4 November 2014 on the emission standards for certain types of the installations, fuel combustion sources and incineration and co-incineration equipment [5].

Activities to modernise energy facilities enable the energy sector to meet the requirements of EU directives and to achieve a high level of efficiency of individual components of a power unit. However, supervision to ensure the correct operation of power

\footnotetext{
*Corresponding author: aleksandra.brzezinska91@gmail.com
} 
facilities, including their installations, and appropriate controls to comprehensively diagnose complex facilities, including electrostatic precipitators, are most important.

\section{Structure of a thermal power plant}

The thermal power plant has a complex structure which, apart from its main equipment (boiler, turbine, generator, transformer), consists of multiple circuits and pieces of auxiliary, control, signalling, security and measurement equipment. Its structure should ensure the lowest possible cost of electricity generation and the greatest possible efficiency of individual transformations [6]. Some part of energy generated in the power plant serves own needs. It is drawn directly from generator terminals and sent via a transformer to specific power plant equipment. The most important pieces of power plant equipment serving own needs include: water and steam circulation equipment (feed pumps, condenser equipment), combustion equipment (fans, dust collectors, including electrostatic precipitators), fuel transportation equipment and machines, coal pulverisers, turbine operating equipment, a generator cooling system, measurement, security, control and signalling equipment, lighting [7].

As certain equipment needs to be in constant operation, it has a back-up power supply system (two or three pieces of equipment are installed to serve a similar purpose, but normally only one of them is active) and some part of electricity in power plants is used to constantly power the most important equipment in the energy conversion process $[15,16]$.

\subsection{Electrostatic precipitator as a power unit component}

Apart from fuel combustion installations, power units include fuel dedusting equipment. Development trends in this area focus on making their structure and operation more efficient [8]. The electrostatic precipitator is among complex machines making up the power unit whose structure can be divided into five characteristic groups $[9,10]$ :

- Structural components: foundations for the ESP's heavy structure to be laid on them later, casing of dumping hoppers for ash and the equipment's frame, i.e. its support structure with pivot bearings and a chamber divided into an upper and lower part.

- Mechanical part: bearings mounted on pillars, rapper shafts with hammers, a diffuser and a confusor.

- Electrical equipment: transformer units and their installations, automation and control systems, auxiliary equipment.

- Thermal insulation group: mineral wool resistant to high temperatures.

- A system of stairs, landings and platforms to access inspection manholes located on the roof, chamber side walls and dumping hopper side walls.

Any damage to one or more of the ESP's indicated components does not have to lead to the facility's complete shutdown, but any undesirable event related to the occurrence of damage makes the operation of equipment less efficient in a certain way. Complex machines can be considered as the so-called "renewable facilities" only if such damage to the facility's components can be repaired and if performed activities lead to making such equipment operable again [17]. The repair of the facility by a qualified team should not normally interfere with key tasks performed on site.

\section{Conditions for diagnosing electrostatic precipitators' state}

Measurements in the energy industry are made regularly during a warranty period after which they are only made upon order by an investor in accordance with PN-Z-040307:1994 "Tests for dust content. Measurement of concentration and mass flow rate of particulate matter in waste gases by gravimetric method" [11]. There is neither a predetermined time interval, which would indicate deadlines for tests to diagnose the electrostatic precipitator's current state, nor a list of parameters to be checked during inspections. The checks to date have covered the values, which are set out in the 
Regulations of the Minister of the Environment, relating to combustion equipment, i.e. $\mathrm{NO}_{\mathrm{x}}, \mathrm{SO}_{\mathrm{x}}$ and dust. Laboratories, which make measurements, test processes, systems and energy equipment, have their own list of offered parameters which can be tested during a check, but it is a person ordering the test who ultimately chooses values to be measured.

If a new emission standard for dust cannot be met, the first idea is usually to modernise the existing electrostatic precipitator power supply system or to invest in a new facility. Enhancements or repairs of electrostatic precipitators are not the cheapest solutions and often make it necessary to shut down a boiler for a few months. Therefore, it is so important to use an appropriate system to diagnose electrostatic precipitators' technical state in order to set deadlines for the machine's repairs, modernisations or inspections, in order to systematically plan works to improve the facility's operation and ultimately to help reduce the electrostatic precipitator's operational costs.

\section{Process of diagnosing the electrostatic precipitator's technical state}

The process of diagnosing the technical state of the electrostatic precipitator as a complex facility, which is among critical equipment in the power unit, should clearly make it possible to identify certain components, parts, material in the context of recognising their degradation. The procedures for diagnosing the electrostatic precipitator's state and controlling the facility's operability, which are proposed in this paper, list individual steps dedicated to the Maintenance Services which develop maintenance, modernisation or service plans for the facility. Additionally, the specific procedures were supplemented with algorithms to ultimately localise damage and to control the progressive degradation of the existing ESPs' state [12].

\subsection{Procedure for assessing the ESP's technical state}

To correctly assess the electrostatic precipitator's technical state, it is important to use tools providing a full insight into its current operation. Given its important function (purification of waste gases from harmful dust particles resulting from the fuel combustion process), the electrostatic precipitator must be guaranteed failure-free operation. The proposed scope of the procedure includes an assessment of the machine's (electrostatic precipitator's) technical state performed during operation and control activities to analyse the facility's operation on an ongoing basis, and activities to detect damage: fatigue, aging, random damage, and the electrostatic precipitator's deteriorating structural and mechanical components. As part of the procedure for assessing the electrostatic precipitator's technical state, the following procedure for individual teams supervising the facility's operation should be distinguished:

1. Assessment of the technical state based on the visual inspection and detection of failures, damage, defects, changes in the waste gas purification process during the electrostatic precipitator's operation:

- diagnosis of failures by telephone based on $\mathrm{mA}$ and $\mathrm{kV}$ values, and information provision (company performing tests for the energy area);

- internal and external inspection of electrostatic precipitators to detect the cause of failure (mechanic at the Maintenance Department together with the Head of the Maintenance Department) if damage prevents the facility from further operation;

- technical supervision of repair works on site (moderniser/repairer responsible for the area of electrostatic precipitator repairs);

- operational optimisation of mechanical and electrical equipment (moderniser/repairer and the company performing tests for the energy area);

- implementation of a procedure for preventing electrostatic precipitators' inoperability (NZU) depending on changes in the combustion process (Head of the Maintenance Department); 
- operational test - testing and monitoring electrostatic precipitators' operation (moderniser/repairer, the Head of the Maintenance Department and the company performing tests for the energy area);

- technical report together with documentation on the removal of the cause of failure or the repair of malfunction (moderniser/repairer, the Head of the Maintenance Department and the company performing tests for the energy area).

2. Assessment of the electrostatic precipitator's technical state based on an algorithm for selecting a test to control the technical state of and localise damage to the facility:

- preparation of data for their acquisition;

- optimisation of a set of values of diagnostic parameters (only if set $\mathrm{Y}$ is large, e.g. $\mathrm{m}>10)$;

- organisation of the data set by determining set $\left\{\mathrm{s}_{\mathrm{i}}\left(\Theta_{\mathrm{k}}\right), \mathrm{i}=1, \ldots, 1 ; \mathrm{k}=1, \ldots, \mathrm{K}\right\}$;

- testing the significance of changes in values of diagnostic parameters $\left\{\mathrm{y}_{\mathrm{j}}\left(\Theta_{\mathrm{k}}\right)\right\}$ depending on the state of set $\left\{\mathrm{s}_{\mathrm{i}}=\mathrm{f}\left(\Theta_{\mathrm{k}}\right) ; \Theta_{\mathrm{k}} \in\left(\Theta_{1}, \Theta_{\mathrm{b}}\right)\right\}$, i.e. which diagnostic parameter "best" describes the state of the equipment's inoperability $-\mathrm{s}$;

- specification of a Boolean matrix:

- 1 - when a change in the state of the equipment's inoperability $-\mathrm{s}_{\mathrm{i}}$ causes significant changes in values of diagnostic parameter $\mathrm{y}_{\mathrm{j}}$;

- 0 - when a change in the state of the equipment's inoperability $-\mathrm{s}_{\mathrm{i}}$ causes no significant changes in values of diagnostic parameter $\mathrm{y}_{\mathrm{j}}$.

- determination of an optimal method for selecting a test to control the state and to localise damage depending on the size of the set of diagnostic parameters and the machine's operation time:

- development of an optimal method for selecting a test to control the machine's state. The test to control the state (TCS) to be selected based on the Boolean matrix - the TCS as a vector of logical values $(0,1)$ of diagnostic parameters and its analogical vector of states: $\left\{\left(\mathrm{y}_{1}, \ldots, \mathrm{y}_{\mathrm{n}}, \ldots, \mathrm{y}_{\mathrm{N}}\right)\right\} \Rightarrow \mathrm{S}_{0} \vee \mathrm{S}_{1}=\left\{\left(\mathrm{s}_{1}, \ldots, \mathrm{S}_{\mathrm{n}}, \ldots\right.\right.$, $\mathrm{S}_{\mathrm{N}}$ ) for the state of the equipment's operability $\mathrm{S}_{0}$ and the state of the equipment's inoperability $\mathrm{S}_{1}$;

- testing the impact of the machine's operation time on an optimal diagnostic test;

- development of an optimal method for selecting a test to localise damage to the machine (test to localise damage (TLD) to be selected based on the Boolean matrix).

- interpretation of results of tests to control the electrostatic precipitator's (ESP's) state.

\subsection{Procedure for the genesis of the ESP's technical state}

The procedure covers the genesis of the ESP's technical state performed after assessing the state during the electrostatic precipitator's (ESP's) operation. Symptom genesis is an innovative approach which makes it possible to register values of the ESP's diagnostic parameters and states during operation. Based on collected data and the equipment's visual inspection, it allows for determining what caused and what conditions accompanied the state of the equipment's inoperability. As part of the procedure for the genesis of the electrostatic precipitator's technical state, the following procedure for individual teams supervising the facility's operation should be distinguished:

1. Genesis of the technical state based on registered values of the electrostatic precipitator's diagnostic parameters and states during its operation to date:

1. constant monitoring of the following: discharge electrode rappers, collection electrode rappers, hopper heating, stand-off or rotating insulator heating, hopper ash level sensors' state, high voltage systems in each zone, dust collection from under hoppers (separate installation); 
2. continuous measurement of the ESP's diagnostic parameters: concentration of waste gas components, i.e. $\mathrm{SO}_{2}, \mathrm{NO}_{\mathrm{x}}, \mathrm{CO}, \mathrm{H}_{2} \mathrm{O}, \mathrm{O}_{2}$ and dust, volumetric flow rate of waste gas, moisture content in waste gas, temperature of waste gas, temperature inside the ESP's chamber, static pressure;

3. when the state of the equipment's operability changes into the state of the equipment's inoperability, it is necessary to take dust samples and determine dust particle size and content of: $\mathrm{Cd}, \mathrm{Cr}, \mathrm{Ni}, \mathrm{Pb}, \mathrm{V}, \mathrm{Cu}, \mathrm{Al}, \mathrm{As}, \mathrm{Zn}, \mathrm{H}_{2} \mathrm{SO}_{4}, \mathrm{NH}_{3}, \mathrm{TOC}$ (total organic carbon), TC (total carbon), share of flammable and non-flammable parts;

4. collecting all measurement results, performing necessary calculations and determining the relationship between changes in the genesis value of the diagnostic parameter with a genesis error and the limit value of the diagnostic parameter;

5. determining the relationship between changes in the genesis value of the diagnostic parameter with a genesis error and the limit value of the diagnostic parameter (algorithm for the genesis of the ESP's technical state according to the scheme of estimating values of diagnostic parameters) $[13,14]$.

The set of parameters to be optimised: by calculating values of criterion functions and weights of diagnostic parameters based on input data for the selected facility (ESP) in the Dedicated Diagnostic System for the ESP (DDSESP). As a criterion for selecting the diagnostic parameter(s), one should assume the maximum weight values wj and select diagnostic parameters according to the criterion adopted. The procedure allows for selecting diagnostic parameters as prefered by a system operator (Head of the Maintenance Department) and updating weigth values for new sets of selected diagnostic parameters $[12,13,14]$.

The genesis of the ESP's state to be performed by:

- determining the genesis value of the diagnostic parameter and the genesis error (only for a discrete event notation);

- determining the minimum distance of the genesis value of the diagnostic parameter to its limit value and testing the impact of operational conditions (number of parameters, number of time series) on the state's genesis;

- visualising and recording approximation or interpolation functions for the selected ESP's parameters;

- estimating the cause of damage to the machine based on the minimum distance of the genesis value of the diagnostic parameter to its limit value, values of the machine's process parameters, values of ambient parameters and additional events.

Collecting materials and information on causes of damage to the system of dust collection from under hoppers (taking into account hopper ash level sensors' state) together with taking a series of photographs to illustrate the actual state of individual mechanisms and parts of the dust collection system. It is also necessary to record the date and location of the damage. Information necessary for data generation based on the algorithm for the genesis of the ESP's technical state according to the scheme of estimating values of diagnostic parameters.

\subsection{Procedure for forecasting the ESP's technical state}

The basic purpose of the procedure for forecasting the ESP's technical state is to present a sequence of tasks necessary for presenting a track record of past events, which occurred during the ESP's operation, so that unfavourable events in the ESP's operation (ESP's damage putting the facility at risk of being shut down) can be predicted in the future based on the data collected. As part of the procedure for forecasting the electrostatic precipitator's 
technical state, the following procedure for individual teams supervising the facility's operation should be distinguished:

\section{Forecast of the ESP's technical state based on values of parameters of the ESP's state during operation and the ESP's completed modernisations and repairs:}

- developing a model process of diagnosing the ESP based on identified symptoms and collected information on: operation of discharge electrode rappers, collection electrode rappers, hopper heating, stand-off or rotating insulator heating, hopper ash level sensors' state, high voltage systems in each zone, dust collection from under hoppers (separate installation).

Having analysed the process of diagnosing the ESP in detail, the following necessary diagnostic parameters for the ESP were determined: concentration of waste gas components, i.e. $\mathrm{SO}_{2}, \mathrm{NO}_{\mathrm{x}}, \mathrm{CO}, \mathrm{H}_{2} \mathrm{O}, \mathrm{O}_{2}$ and dust, volumetric flow rate of waste gas, moisture content in waste gas, temperature of waste gas, temperature inside the ESP's chamber, static pressure. The model process of forecasting the ESP's state must be developed based on information on the course of modernisation, repair activities and documentation presenting the genesis and assessment of the ESP's technical state.

- collecting local values of the measure of similarity between instantaneous states and model time series;

- generating a model of the ESP's forecast state also based on an algorithm for forecasting the ESP's technical state;

- calculating forecast values of the measure of probability based on collected data on the ESP's operation, modernisations and repairs;

- coming to conclusions on future states of selected mechanisms and parts of the tested facility (ESP).

2. Algorithm for forecasting the ESP's technical state:

- forecasting the value of diagnostic parameter $\mathrm{y}_{\mathrm{j} * \text { : }}$

- by Brown-Mayer adaptive method, grade 1 (B-M1), with coefficient $\alpha=(0.1-0.9)$ for forecast horizon $\tau=3 \Delta \mathrm{Q}$ set for time interval $(\mathrm{Q} 1, \mathrm{Qb})$ - the method used when a forecast variable is almost constant and minor random fluctuations occur;

- by Holt adaptive method with coefficient $\alpha=(0.05-0.3)$ and $\beta=(0.4-0.9)$ for forecast horizon $\tau=3 \Delta \mathrm{Q}$ set for time interval (Q1,Qb) - the method used when persistent time trends in a time series are observed;

- by analytic methods (linear, exponential and power methods of the first, second, and third grade) for forecast horizon $\tau=3 \Delta \mathrm{Q}$ set for time interval $\left(\mathrm{Q}_{1}, \mathrm{Q}_{\mathrm{b}}\right)-$ the method allows for finding a trend function which will meet the set criteria and will optimally adapt to the forecast variable's time series (it is important to select an appropriate analytical form of the trend function);

- setting a deadline for the next servicing and diagnosing of the machine $\Theta_{\mathrm{d}}$.

\section{Summary}

The coal power stations have the right number of starts machines (and exceeding permissible parameters that occur in such states), sooner or later there are problems and damages. Cracks appear, followed by failures of lower or higher severity. Paradoxically, older power units are technologically more adapted to load changes, because the steam parameters are not exorbitant. For some power units, further solutions are introduced enabling undervaluation lower of power. Unfortunately, most of the power units are currently probably already largely exploited. The number of work hours the power units goes in hundreds of thousands, slowly exceeding the thresholds allowed, and their current work is based on multiple modernizations. Unfortunately, the history of the power units exploitation is usually not collected, as a result, the actual state of the devices is not known. 
Increases over the years, probability of occurrence of more failures and deterioration of the availability coefficients. Of course each of the consortium (manufacturing companies) reports internal reliability parameters and costs incurred for the repair of facilities, but the additional cost alone caused by large load changes and more boiler withdrawals from use, unfortunately it is a problem that is frequently off in the juxtaposition. Therefore, it is necessary to supervise the correct operation of the power facilities, including installations is entering in its composition, and conducting reliable controls aimed at comprehensive diagnosis of complex objects. For financial reasons, the introduction of a methodology to monitor the ESP degradation and control of the current operation of the facility is of key importance.

\section{References}

1. M. Kudełko, Czynniki determinujace rozwój krajowego sektora energetycznego analiza wrażliwości, Journal of Management and Finance, 13, 255-256 (2015).

2. Green Paper, A European Strategy for Sustainable, Competitive and Secure Energy, Brussels, 17-18 (2006).

3. EU, Directive 2010/75EU of the European Parliament and of the Council of 24 November 2010 on industrial emissions (integrated pollution prevention and control), (Recast), 1-2 (2010).

4. Ministerstwo Środowiska, Rozporządzenie Ministra Środowiska z dnia 30 października 2014 r. w sprawie wymagań $w$ zakresie prowadzenia pomiarów wielkości emisji oraz pomiarów ilości pobieranej wody, 2014/1542, 1-3 (2014).

5. Minister for the Environment in Poland, Regulation of the Minister for the Environment of 4 November 2014 on the emission standards for certain types of installation, fuel combustion plants and waste incineration or co-incineration facilities, Dziennik Ustaw, 2014/1546, 1-4 (2014).

6. B. Zaporowski, Technologie wytwarzania energii elektrycznej dla polskiej elektroenergetyki, Energy Policy Journal, 18, 29-44 (2015).

7. T. Chmielniak, A. Rusin, H. Łukowicz, Modernizacja i rewitalizacja istniejacych bloków węglowych ważnym warunkiem stabilności sektora wytwarzania elektryczności, Energy Policy Journal, 19, 49-59 (2016).

8. A. W. Yuen, Collector Current Density and Dust Collection in Electrostatic Precipitators, VDM Verlag Dr. Mueller, 1-7 (2008).

9. F. K. Fuliful, A. A. Hamood, Collection Efficiency of Wire- Duct Electrostatic Precipitator, LAP Lambert Academic Publishing, 11-20 (2017).

10. H. A. Ziedan, Modeling of Corona Discharge in Wire-duct Electrostatic Precipitators, LAP Lambert Academic Publishing, 35-44 (2016).

11. PN-Z-04030-7:1994, Ochrona czystości powietrza. Badania zawartości pytu. Pomiar stężenia i strumienia masy pylu w gazach odlotowych metoda grawimetryczna, PKN, 1-7 (1994).

12. B. Żółtowski, D. Landowski, B. Przybyliński, Projektowanie Eksploatacji Maszyn, Wydawnictwo Naukowe Instytutu Technologii Eksploatacji - Państwowego Instytutu Badawczego, 212-215 (2012).

13. H. Tylicki, B. Żółtowski, Genezowanie stanu maszyn, Wydawnictwo Naukowe Instytutu Technologii Eksploatacji - Państwowego Instytutu Badawczego, 29-45 (2012).

14. H. Tylicki, B. Żółtowski, Rozpoznawanie stanu maszyn, Instytutu Technologii Eksploatacji - Państwowego Instytutu Badawczego, 11-66 (2010).

15. M. Żółtowski, Informatyczne systemy zarządzania $w$ inżynierii produkcji. Wydawnictwo ITE-PIB, Radom 2011. 
16. B. Żółtowski, Metody inżynierii wirtualnej $w$ badaniach stanu, zagrożeń bezpieczeństwa i środowiska eksploatowanych maszyn. Wyd. UTP, Bydgoszcz 2012.

17. B. Żółtowski, Badania zagrożeń utraty zdatności środowiskowych systemów technicznych. WU UTP, Bydgoszcz 2013, s.181.

18. A. Brzezińska, B. Żółtowski, Dozorowanie procesu technologicznego pracy bloków energetycznych $w$ diagnostycznej strategii eksploatacji, Opracowanie wewnętrzne, 2017. 